\section{Preliminary Training for the Flying Services}

THE Secretary of State for Air has announced that it is proposed to establish an Air Training Corps to provide preliminary training for men desiring to enter the Flying Services. The scheme will be divided into three parts : units will be formed at the universities, at secondary schools, and locally. At the universities, the Air Ministry is arranging a six months course for potential pilots and navigators ; candidates will join the university air squadrons for instruction in service subjects, and at the same time they will attend courses given by university lecturers on mathematics and mechanics, and on either electricity and magnetism, engineering, meteorology or navigation. They will be full members of the university, and will live in colleges and hostels so far as possible. All expenses, apart from certain personal items, will be paid for by the Air Ministry. Candidates must be between 17 years and 18 years 8 months on February 15 and will be selected on nomination by headmasters; the first course begins on April 15.

Local units, for which the organization of the Air Defence Cadet Corps will be used, will be formed, and the Air Ministry is providing for lectures arranged by local authorities on mathematics and English. For the schools scheme, boys should be between 16 and 18 years of age, and they will carry out a syllabus approximating to that of an initial training wing of the R.A.F., the principal subjects being navigation, mathematics, signals and the theory of flight. Financial assistance will be provided by the State.

\section{Sir Henry Head's Bequest to the Royal Society}

UNDER the terms of the will of the late Sir Henry Head, the Royal Society is named as residuary legatee, and it is believed that a substantial sum of money will go to the Society in due course. The broad terms of direction in the will are that the money "shall be applied for the purpose of the advancement in England of the science of medicine in the widest sense"; for this purpose a committee of not less than three or more than five is to be appointed to administer the fund. Without imposing any obligation on this committee, the will suggests that the fund, or part of it, might be used to establish professorships or similar posts or research scholarships in a branch of medical science at medical or other educational institutions. Sir Henry Head, who died on October 8 last, had been a fellow of the Royal Society since 1899, and was awarded a Royal Medal of the Society in 1908.

\section{Reading Machine for Microfilm}

The Committee on Scientific Aids to Learning, which reports to the U.S. National Research Council, is promoting, among other things, the use of microfilm, and, as a result of its efforts, a reading machine is being manufactured which will be sold at a retail price of 32 dollars. A grant from the Committee has made it possible for Mathematical Reviews to obtain a limited number of these machines, which will be available to those who have paid their subscriptions, at the appropriate rate, to Mathematical
Reviews, in advance for three years beginning this month. The history of the 'reader', known as the Students Microfilm Reader, goes back to the autumn of 1939. At that time an advisory group on micro. photography to the Committee on Scientific Aids to Learning, composed of Mr. Keyes D. Metcalf, director of the Harvard University Library (chairman), Profs. Ralph D. Bennett and Ernest I. Huntress of Massachusetts Institute of Technology, Dr. Vernon D. Tate of the National Archives, and Dr. Irvin Stewart, director of the Committee on Scientific Aids to Learning (ex officio), was requested to consider the possibilities of designing and making available a simple, inexpensive microfilm reading machine for the use of the individual student.

Eventually the Spencer Lens Company was autho. rized to build a model, and the Committee on Scientific Aids to Learning has now signed a contract for a number of these machines; in addition, they will be placed on the market by the Spencer Lens Company. Emphasis has been placed throughout on suitability for the purpose for which the reader was designed, simplicity and low cost. No claims are made for extreme convenience, beauty, ready portability, or universality. The Students Microfilm Reader is not intended to compete with existing reader equipment, which is generally more suited for commercial and library use. It was developed specifically to permit the individual student to utilize in his own study or laboratory microphotographic copies which he may have made personally or procured from one of the existing sources of supply. The address of Mathematical Reviews is American Mathematical Society, Brown University, Providence, R.I.

\section{Developments in B.B.C. Services}

NEw programmes for France and Luxembourg and an additional bulletin in Polish are included in recent developments made in the B.B.C.'s European Service (Practical Wireless, Feb. 1941). A Sunday programme for French listeners entitled "Une demi heure du Dimanche" which is now broadcast during 3-3.30 p.m. B.S.T., includes a review of the week's events and talks on general interest and religious subjects. It is transmitted on the wave-lengths $49 \cdot 59$ metres and $25 \cdot 29$ metres. The new programme for Luxembourg is broadcast on the last day of the month between 8.0 and 8.15 p.m. B.S.T. in the period entitled "Radio Belgique". The wave-lengths on which this transmission may be received are $285 \cdot 7$ metres, 261.1 metres, 49.59 metres and 30.96 metres. A third news bulletin in Polish was recently added to the B.B.C.'s broadcasts in Europe and can be heard during $4.15-4.30$ p.m. B.S.T. each day on $49 \cdot 59$ metres and $25 \cdot 29$ metres.

Mr. R. C. McCall, who has been appointed to the B.B.C. staff to organize the new Pacific transmission of the B.B.C.'s Overseas Service, has recently arrived in Great Britain. This provides a further example of the close co-operation between Dominion broadcasting organizations and the B.B.C. Another similar case has been the appointment of Mr. E. L. Bushnell, controller of programmes for the Canadian Broad- 
casting Corporation, to the position of North American programme organizer of the B.B.C. Overseas Service and the work in Great Britain of the Canadian Broadcasting unit.

\section{Control of Lice}

IN the British Medical Journal of November 2, Prof. P. A. Buxton contributes an article on this subject. The crowded sleeping conditions that prevail in some of the air-raid shelters render it likely that outbreaks of body and head lice will occur. In peacetime, at any rate, the body louse is much the rarer of the two races, but it is likely to become more prevalent. At the present time no really effective practical repellent is known. The control measures advised concern the head and body and the disinfestation of clothes, blankets, etc. The best methods for effecting these processes are discussed in some detail. For control on the person the speediest method for eliminating the head louse is the use of one or other of the insecticidal liquids advised. Disinfestation of garments, etc., is best done by the application of heat: 5 minutes at $129^{\circ} \mathrm{F}$. or 45 minutes at $121^{\circ} \mathrm{F}$. are fatal both to the lice and to their eggs or nests. It is not important whether the heat be dry or moist ; but it is essential that the whole of the infested materials should be submitted to the temperature mentioned. Disinfestation of clothes properly done with a domestic hot iron is quite effective. The organization and proper lay-out of disinfesting stations does not lend itself to explanation in a short article, and the reader is referred to the "Army Manual of Hygiene" for information on this aspect of the problem.

\section{Spread of Desertic Conditions}

MUCH has been heard in recent years of soil erosion, due to a variety of causes, emanating usually in illadvised use of the land. In Africa this has been shown to cause the spread of waste or desertic conditions. In a paper in the Geographical Journal of November, on desert versus forest in Eastern Africa, Mr. E. J. Wayland points out that there are climatic deserts and climatic forests and that each will retain its characteristics in spite of man's interference; man can do little to change the aspects of such lands. However, between the essential desert and the essential forest there is forest land which on its desert side is (or was, since in Africa most has been destroyed) a zone of forest-desert equilibrium, disturbable, to the desert's advantage, by Nature or by man. This is the zone of counter forest, and on the true forest side shows a marginal belt where the forest holds as long as natural conditions have sway. In this belt, however, man-made desert is not merely possible but is very general in Africa. All African forest areas with one or two long dry seasons and a rainfall of not more than 30 inches a year may be regarded as marginal in character, and all such areas are liable to soil erosion. Mr. Wayland does not believe that desert will or can spread into the essential forest: the counter forest acts as a buffer that holds in check the spread of the desert conditions.

\section{Prof. Eduard Albert}

Prof. Eduard Albert, a pioneer of modern surgery in Austria, was born at Sznfterberg in Bohemia on January 20, 1841. He received his medical education at the University of Vienna, where he studied under Hyrtl, Skoda, Brücke, Oppolzer and Rokitansky. After qualifying in 1867 he became assistant to Prof. Johann Dumreicker, professor of surgery in the Vienna Faculty. In 1872 he was appointed professor of surgery at Innsbruck where he remained for eight years and then succeeded Dumreicher at Vienna. It was here that he gained a European reputation by his introduction of Listerian antisepsis, which Dumreicher had rejected, and attracted a number of students who afterwards became eminent surgeons. Albert was well known in Great Britain, where he was elected an honorary fellow of the Royal College of Surgeons in July 1900. His principal publications were "Diagnostik der chirurgischen Krankheiten", "Lehrbuch der Chirurgie" and "Beiträge zur Geschichte der Chirurgie". He died on September 20, 1900.

\section{Albert King}

Albert Freeman Africanus King, a pioneer in malariology, was born at Bicester, Oxfordshire, on January 18, 1841, the son of a doctor interested in the colonization of Africa. At the age of ten he migrated with his parents to the United States. He received his medical education at the National Medical College at Washington, where he graduated at the age of twenty, and four years later obtained the degree of M.D. at the University of Pennsylvania. $\mathrm{He}$ settled in practice in Washington, where he attended Abraham Lincoln at the time of his assassination in 1865. He was for many years professor of obstetrics in the George Washington University and in the University of Vermont, which latter institution conferred on him the degree of LL.D. in 1904. He was the author of a "Manual of Obstetrics", which went through eleven editions; but he is best known for a paper entitled "Insects and Disease-Mosquitoes and Malaria" read before the Philosophical Society of Washington on February 10, 1882, and published in the Popular Science Monthly in September 1883, in which he gave nineteen reasons for believing that malaria is transmitted by the mosquito. He died in 1914.

\section{Announcements}

THE following officers of the Royal Society of South Africa have recently been elected: President, L. Crawford ; Treasurer, R. W. James; Secretary, A. J. H. Goodwin; Editor, Mrs. M. R. Levyns; Librarian, E. Newbery ; New Additional Members of Council, G. Arnold, W. F. Barker, M. Rindl.

IT is hoped to hold the first meeting of the Colour Group of the Physical Society at the Polytechnic, Regent Street, London, W.1, at 2.0 p.m. on February 12. The first portion of the meeting will be devoted to a discussion of the draft constitution of the Group. During the second portion of the meeting four short papers will be read on "Colour Tolerance". 